\title{
LABORATORY PREDICTORS OF MATERNAL AND FOETAL OUTCOMES IN EARLY ONSET PREGNANCY- INDUCED HYPERTENSION
}

\author{
Mangala Chandrapalsingh Rajput ${ }^{1}$, Uday Chandrapalsingh Rajput², Sujata Waman Gandhare 3 , Aarti Avinash Kinikar4 \\ 1 Professor and HOD, Department of Obstetrics and Gynaecology, Wanless Hospital, Miraj. \\ ${ }^{2}$ Associate Professor, Department of Paediatrics, BJGMC, Pune. \\ ${ }^{3}$ Consultant, Department of Obstetrics and Gynaecology, Wanless Hospital, Miraj. \\ 4 Professor and HOD, Department of Paediatrics, GMC, Miraj.
}

\section{ABSTRACT}

\section{BACKGROUND}

The aim of this study is to assess the laboratory predictors of poor foetal and maternal outcomes in Early Onset Pregnancy Induced Hypertension (EOPIHT).

\section{MATERIALS AND METHODS}

This prospective observational study was conducted in the maternity ward of Wanless Hospital, Miraj, a tertiary care hospital in Western Maharashtra catering to rural and semi-urban population from April 2011 to March 2013. The study enrolled 100 pregnant women between 20 to 34 weeks of gestation with pregnancy-induced hypertension. The women had a blood pressure of more than $140 / 90 \mathrm{mmHg}$ with or without proteinuria after 20 weeks of pregnancy. Logistic regression analysis was done to identify the significant predictors of poor maternal and foetal outcomes.

\section{RESULTS}

The most common hypertensive disorder was seen in 34 (34\%) pregnant women with severe preeclampsia; gestational hypertension in 26 (26\%), mild preeclampsia in 11 (11\%), eclampsia in 19 (19\%) and HELLP syndrome in 10 (10\%). Immediate termination of pregnancy was done in $90 \%$ of cases (46\% vaginal and 56\% LSCS). Expectant management was given for 3 to 8 days in only $10(10 \%)$ cases. There were 2 maternal deaths, both with HELLP syndrome due to ARF and Pulmonary oedema. All 100 mothers delivered premature babies - 12 AGA, IUGR 47 with 41 intrauterine deaths. NICU admission was needed in all 59 cases who survived. Laboratory findings of proteinuria $(p<0.05)$, thrombocytopenia $(p<0.001)$, deranged liver enzymes ( $p<0.001)$, hyperuricaemia of $>6.0 \mathrm{mg}(\mathrm{p}<0.05)$ and haemoglobin $>12 \mathrm{gm} \%(\mathrm{p}<0.05)$ were associated with poor maternal outcomes. Poor foetal outcome was dependent on gestational age $(p<0.01)$, severe hypertension $(p<0.05)$, proteinuria $(p<0.05)$ and deranged liver enzymes $(p<0.01)$ in the mother.

\section{CONCLUSION}

Simple laboratory parameters are useful predictors of poor maternal and foetal outcomes in early onset pregnancy-induced hypertension. Early termination of pregnancy will help in reducing poor maternal outcomes. Poor foetal outcomes can be reduced with close pregnancy monitoring and improved premature baby care.

\section{KEYWORDS}

Early Onset Pregnancy Induced Hypertension, Laboratory Parameters, Maternal Outcome, Foetal Outcome.

HOW TO CITE THIS ARTICLE: Rajput MC, Rajput UC, Gandhare SW, et al. Laboratory predictors of maternal and foetal outcomes in early onset pregnancy-induced hypertension. J. Evolution Med. Dent. Sci. 2016;5(102):7455-7459, DOI: $10.14260 /$ jemds/2016/1688

\section{BACKGROUND}

Hypertensive disorders during pregnancy constitute 7 to $10 \%$ of pregnancies, of which nearly 12 - $22 \%$ have unfavourable outcomes.1,2 Pregnancy Induced Hypertension (PIH) still remains an ill understood and underestimated disease. The usual markers in developing countries like poor antenatal care, illiteracy, lack of awareness and poverty in developing countries continue to favour these nightmares of pregnant mothers. ${ }^{1}$

Financial or Other, Competing Interest: None.

Submission 16-11-2016, Peer Review 08-12-2016,

Acceptance 16-12-2016, Published 22-12-2016.

Corresponding Author:

Dr. Uday Chandrapalsingh Rajput,

C/o. Dr. Mangala Rajput,

Doctors' Quarters,

Wanless Mission Hospital,

Miraj-416410, Sangli,

Maharashtra.

E-mail: drudayrajput@gmail.com

DOI: $10.14260 /$ jemds $/ 2016 / 1688$
Masking of PIH symptoms with simple medications may delay its diagnosis leading to poor maternal and foetal outcomes.

Approximately 1,00,000 women die worldwide per annum because of eclampsia.[3] It is said that preeclampsia and eclampsia contribute to death of a woman every 3 minutes worldwide. ${ }^{4}$ Preeclampsia is a common dangerous condition for both mother and baby and is also predictable in onset and progression, cured only by termination of pregnancy.

Hypertensive Disorders of Pregnancy (HDP) are multisystem diseases, which include chronic (pre-existing) hypertension, gestational hypertension, preeclampsia, eclampsia and preeclampsia superimposed on chronic hypertension. ${ }^{3}$

The high perinatal mortality in women with HDP is mainly due to premature delivery and growth restriction.5,6 A secondary analysis from the World Health Organisation (WHO) multi-country survey has shown that there were about 3- and 5-fold increased risk of perinatal death in women with 
preeclampsia and eclampsia respectively, as compared to women with no preeclampsia/eclampsia. ${ }^{7}$

Although, there is a large body of literature that described the magnitude and associated complications of HDP, little is done to assess the predictors of perinatal mortality, particularly in low and middle income countries. ${ }^{8-10}$ This is despite the fact that the majority of perinatal deaths due to complications of HDP have occurred in the low and middle income countries.[11-14] This study was planned with an objective of determining the clinical and laboratory predictors of maternal and foetal outcomes in early onset pregnancyinduced hypertension, so as to appropriately manage these cases early and prevent their progression to serious forms and complications.

\section{MATERIALS AND METHODS}

This prospective observational study enrolled 100 cases of pregnant women with early onset PIH, i.e. rise of BP more than $140 / 90$ with or without proteinuria between 20 to 34 weeks of gestation. The study was conducted in the high risk obstetrics unit of tertiary care referral Wanless Hospital at Miraj, catering to rural and peri-urban population.

The inclusion criteria was all registered diagnosed cases of early onset PIH, i.e. between 20 to 34 weeks of gestation who were categorised as gestational HT, mild preeclampsia, severe preeclampsia, eclampsia and HELLP syndrome.

The exclusion criteria was patients with rise of B.P. 140/90 with or without proteinuria before 20 weeks and after 34 weeks and those with pre-existing medical disorder leading to rise of B.P. like essential hypertensive, chronic hypertension and diabetes.

\section{Study Procedure}

1. Pregnant women enrolled in the study were admitted to the ward and a detailed history and examination was carried out as per pre-designed proforma. Details of risk factors for PIH were documented. All mothers underwent following investigations - CBC with peripheral smear, PT APTT, RFT, LFT, Obstetric USG with Doppler. Patients were given bed rest, antihypertensives like Depin, Aldomet or Labetalol orally. Antihypertensives were initiated if B.P. was > 160/100 mmHg. All cases were given Inj. Betamenasone as per standard of care. Expectant line of management included regular maternal and foetal monitoring. Maternal monitoring included B.P. every 6 hrs., daily urine for protein, urine output, daily weight and impending signs of eclampsia. Foetal monitoring included daily foetal kick count, daily NST, biweekly USG and Doppler. Prophylactic Inj. MgSo4 was used if there was evidence of impending eclampsia. Blood and blood products were used if there was evidence of abnormal coagulation profile. Foetal outcomes were measured as intrauterine death, intrauterine growth restriction or appropriate for gestational age. Maternal outcome were measured as mortality or morbidity (abruption placentae, pulmonary oedema, acute renal failure, DIC, cortical venous thrombosis, post-partum haemorrhage).

2. Data analysis was done by using Microsoft Excel 2007 and SSPE for logistic regression analysis.

3. Written informed consent from patient and Ethical Committee approval from Institutional Ethical Committee were taken.

\section{RESULTS}

The total number of deliveries from April 2011 to March 2013 were 1000, of which early onset PIH (20 to 34 wks.) was seen in 100 cases. The overall incidence of PIH at the centre being $10 \%$ with contribution of gestational hypertension $26(26 \%)$, mild preeclampsia 11 (11\%), severe preeclampsia 34 (34\%) eclampsia 19 (19\%) and HELLP syndrome 10 (10\%).

\begin{tabular}{|c|c|}
\hline Age Distribution & \\
\hline 16 to 20 & $13(13 \%)$ \\
\hline 21 to 25 & $53(54 \%)$ \\
\hline 26 to 30 & $28(28 \%)$ \\
\hline 31 to 35 & $4(4 \%)$ \\
\hline$>35$ & $2(2 \%)$ \\
\hline Gravida Distribution 1 & $63(63 \%)$ \\
\hline G 2 & $16(16 \%)$ \\
\hline G 3 & $11(11 \%)$ \\
\hline G 4 & $7(7 \%)$ \\
\hline G 5 & $3(3 \%)$ \\
\hline Risk Factors & $11(11 \%)$ \\
\hline History of PIH in previous pregnancy & $8(8 \%)$ \\
\hline Family history of PIH & $5(5 \%)$ \\
\hline Thrombophilic disorder & $2(2 \%)$ \\
\hline Obesity & $2(2 \%)$ \\
\hline Dyslipidaemia & $0(0 \%)$ \\
\hline Multi-foetal gestation & $95(95 \%)$ \\
\hline Booked outside & $5(5 \%)$ \\
\hline Unbooked & \\
\hline Table 1. Socio-Demographic Characteristics (n 100) \\
\hline
\end{tabular}

In the present study, maximum number of cases $53(53 \%)$ were between the age group of 21 to 25 years with $63(63 \%)$ being primi gravida. Significant risk factor for PIH were booked outside 95 (95\%), history of PIH in previous pregnancy $11(11 \%)$ and family history of PIH8 (8\%) [Ref. Table 1]. 


\begin{tabular}{|c|c|c|c|c|c|c|c|c|}
\hline \multirow[b]{2}{*}{$\begin{array}{l}\text { Laboratory } \\
\text { Parameter }\end{array}$} & \multirow[b]{2}{*}{ Values } & \multirow{2}{*}{$\begin{array}{l}\text { Total } \\
(100) \\
\text { n (\%) }\end{array}$} & \multirow{2}{*}{\begin{tabular}{|c|} 
Gestational \\
Hypertension \\
$(26) \mathrm{n}(\%)$
\end{tabular}} & \multicolumn{2}{|c|}{ Preeclampsia } & \multirow[b]{2}{*}{$\begin{array}{l}\text { Eclampsia } \\
\text { (19) n (\%) }\end{array}$} & \multirow[b]{2}{*}{$\begin{array}{c}\text { HELLP } \\
(10) \mathrm{n}(\%)\end{array}$} & \multirow[b]{2}{*}{ P value } \\
\hline & & & & $\begin{array}{c}\text { Mild (11) } \\
\text { n (\%) }\end{array}$ & $\begin{array}{c}\text { Severe (34) } \\
\text { n (\%) }\end{array}$ & & & \\
\hline \multirow{3}{*}{ Haemoglobin (g/dL) } & $>12$ & $46(46)$ & $13(50)$ & $9(81.81)$ & $14(41.17)$ & $9(47.36)$ & $1(10)$ & $\mathrm{P}>0.05$ \\
\hline & 8 to 12 & $44(44)$ & $11(42.30)$ & $2(18.18)$ & $15(44.11)$ & $9(47.36)$ & $7(70)$ & $\mathrm{P}>0.05$ \\
\hline & $<8$ & $10(10)$ & $2(7.69)$ & 0 & $5(14.70)$ & $1(5.26)$ & $2(20)$ & $\mathrm{P}>0.05$ \\
\hline $\begin{array}{c}\text { Haemolysis on } \\
\text { peripheral blood } \\
\text { smear }\end{array}$ & & $13(13)$ & 0 & 0 & $3(8.82)$ & $3(15.78)$ & $7(70)$ & $\mathrm{P}>0.05$ \\
\hline Thrombocytopenia & $<100,000$ & $13(13)$ & 0 & 0 & $2(5.88)$ & $1(5.26)$ & $10(100)$ & $\mathrm{P}>0.05$ \\
\hline $\begin{array}{l}\text { Altered coagulation } \\
\text { profile }\end{array}$ & PT, aPTT & 37 (37) & 0 & 0 & $27(79.41)$ & $4(21.05)$ & $6(60)$ & $\mathrm{P}>0.05$ \\
\hline $\begin{array}{c}\text { Altered liver } \\
\text { enzymes }\end{array}$ & AST, LDH & $14(14)$ & 0 & 0 & $1(2.94)$ & $3(15.78)$ & $10(100)$ & $\mathrm{P}>0.05$ \\
\hline $\begin{array}{l}\text { Altered renal } \\
\text { functions }\end{array}$ & $\begin{array}{c}\text { BUL, Sr. } \\
\text { Creat. }\end{array}$ & $7(7)$ & 0 & 0 & $4(11.76)$ & 0 & $3(30)$ & $\mathrm{P}>0.05$ \\
\hline \multirow{2}{*}{ Sr. uric acid } & 4.5 to 6 & $35(35)$ & $12(46.15)$ & $7(63.63)$ & $11(32.35)$ & $5(26.31)$ & 0 & $\mathrm{P}>0.05$ \\
\hline & $>6$ & $65(65)$ & $14(53.84)$ & $4(36.36)$ & $23(67.64)$ & $14(73.68)$ & $10(100)$ & $P>0.05$ \\
\hline \multicolumn{9}{|c|}{ Table 2. Laboratory Investigations $(n=100)$} \\
\hline
\end{tabular}

Maximum number (90\%) of patients of early onset PIH were having haemoglobin level between 8 to 12 (g/dL) or > 12 (g/dL). Peripheral haemolysis, thrombocytopenia, altered liver and renal functions were observed in severe pre-eclampsia, eclampsia and HELLP syndrome cases. Maximum cases (79.41\%) in severe preeclampsia group were having deranged coagulation profile. Serum uric acid levels of $>6 \mathrm{mg} \%$ were observed in 65 patients, majority of them were having severe preeclampsia (67.64\%), eclampsia (73.68\%) and HELLP syndrome (100\%). But results are not statistically significant.

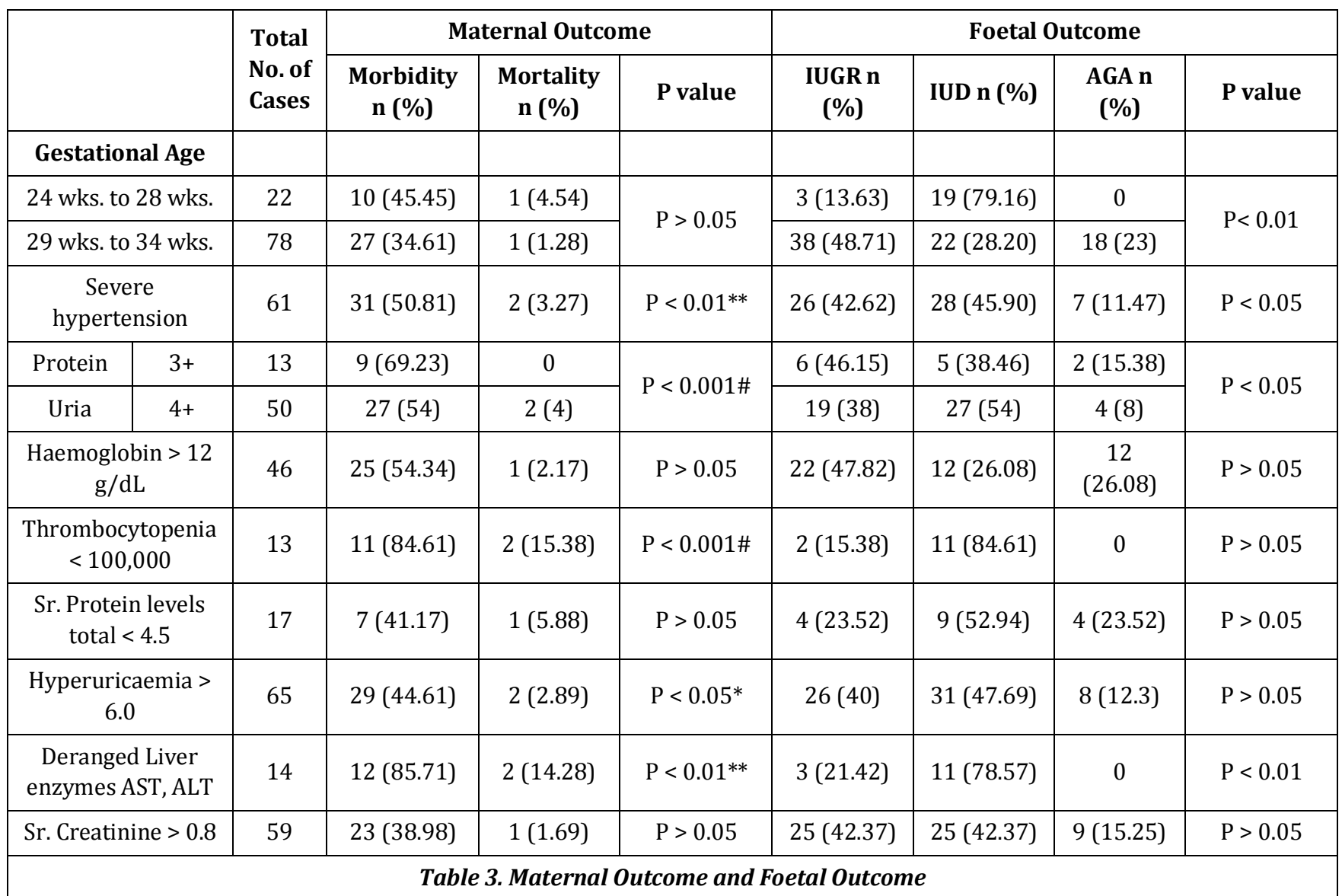


For using logistic regression variables which were significantly associated, i.e. $\mathrm{p}<0.05$, were considered. Among all variables severe hypertension, gestational age, proteinuria, low platelet count, Sr. uric acid levels and deranged liver enzymes were statistically significant.

Using logistic regression, we found that foetal outcome (survival/death) was highly dependent on gestational age, severe hypertension, proteinuria and deranged liver enzymes. Maternal outcome was highly dependent upon severe hypertension, proteinuria, thrombocytopenia and deranged liver enzymes.

There were two maternal deaths due to complications such as ARF, DIC and pulmonary oedema. No patient received expectant line of management.

In the present study expectant line of management was given only in $10(10.00 \%)$ cases, gestational hypertension 7 $(26.92 \%)$ and mild preeclampsia 3 (27.27\%). The prolongation of pregnancy was from 3 days to 8 days. Meticulous maternal and foetal monitoring for earliest diagnosis of complications was done. Immediate termination of pregnancy was required in $90 \%$ and the most common indication for delivery was foetal hypoxia on Doppler study (37\%). The other indications for delivery were already established labour cases with signs of impending eclampsia, abruptio placentae and patient landed up in one of the complications of pregnancy-induced hypertension. No patients with severe preeclampsia, eclampsia and HELLP syndrome received expectant line of management. Prematurity was noted in all 100 cases of the study and AGA in $12 \%$, IUGR in $47 \%$ and all babies were admitted to NICU. Total $41 \%$ were perinatal death and IUD.

\section{DISCUSSION}

In this prospective observational study, we found out early onset PIH with altered laboratory parameters like proteinuria, platelet count, sr. uric acid levels and deranged liver enzymes were significantly associated with poor maternal and foetal outcomes.

The total cases with pregnancy-induced hypertension were 286 out of 1000 pregnancies during the study period with incidence being $28.6 \%$. The cases with early onset pregnancy-induced hypertension were 100 , incidence being $10 \%$. The incidence of gestational hypertension was $26 \%$, preeclampsia $45 \%$ - mild preeclampsia $11 \%$ and severe preeclampsia $34 \%$, eclampsia $19 \%$ and HELLP syndrome $10 \%$. Ganzevoort et al 20075 found similar incidences; however, the incidence of gestational hypertension was more and preeclampsia was less compared to Hwang JL et al, ${ }^{6}$ whereas incidence of eclampsia and HELLP was more in our study. This may be because the overall incidence varies with different geographical region and also the availability and accessibility of antenatal services.

Eskenazi et al $1991^{9}$ and Jophy et al $2004^{15}$ reported incidence of PIH was more common in primi gravida, which were similar to our observation. Many earlier studies reported risk factors for PIH like history of PIH in previous pregnancy, family history of PIH, thrombophilic disorder, obesity, dyslipidaemia [Eskenazi et al 1991, ${ }^{9}$ Cincotta RB et al 1998,16 Gonzalez et al 2000,17 Ros HS et al 2000,18 Sibai BM et al 1997,19 Branch DW et al 200120]. Similar results were observed in our study except incidence of family history was less in the present study, may be due to exclusion of patients with chronic hypertension and other medical disorders.

Looking at the co-relation between laboratory parameters and maternal and foetal outcomes \{Ref. Table 2 and 3 \} gestational age at presentation, severe hypertension, laboratory parameters such as elevated haemoglobin, proteinuria and thrombocytopenia, liver impairment and hyperuricaemia were associated with adverse maternal outcome. Similar observations were noted by Brown MA et al. ${ }^{11}$

Early onset preeclampsia is particularly involved with placental insufficiency and more than half of babies born before 34 weeks will be growth restricted. As in our study all babies born were premature and majority (65.38\%) of the IUGR cases were noted in mothers with gestational hypertension and minority (10\%) with HELLP syndrome. This is due to increasing foetal hypoxia with the severity of the disease. All the IUGR and AGA babies were shifted to NICU for further care. In our study, mild preeclampsia and gestational hypertension was associated with good perinatal outcome. In mild preeclampsia, all the 11 cases $(100 \%)$ required NICU admission and there were no neonatal death, while gestational hypertension group out of 26 babies 9 were perinatal deaths and remaining 17 requires NICU admission. Moore et al $1983^{21}$ reported that severe preeclampsia occurring early in third trimester is associated with high perinatal mortality. Similar results were observed in our study with 16 (47.05\%) perinatal deaths in severe preeclampsia group.

In conclusion, simple laboratory parameters are useful predictors of poor maternal and foetal outcomes in early onset pregnancy-induced hypertension. Early termination of pregnancy will help in reducing poor maternal outcomes. Poor foetal outcomes can be reduced with close pregnancy monitoring and improved premature baby care. Our study has the limitation of a small sample size; hence, to support our findings multicentric studies with larger sample size are needed in future.

\section{REFERENCES}

1. Ray JG, Burrows RF, Burrows EA, et al. MOS HIP: McMaster outcome study of hypertension in pregnancy. Early Hum Dev 2001;64(2):129-43.

2. Joshi-Kale V, Sapre S. Lowered platelet count: a prognostic index in pregnancy induced hypertension. J Obstet Gynecol India 2004;54(3):235-6.

3. Arias F, Daftary S, Bhide A. Practical guide to high risk pregnancy and Delivery. $3^{\text {rd }}$ edn. Elsevier 2008:397- 439.

4. Cunningham FG, Leveno KJ, Bloom SL, et al. Williams Obstetrics. 22nd edn. McGraw Hill 2005:761-808.

5. Ganzevoort W, Rep A, Bonsel GJ, et al. Trial investigators. Dynamics and incidence patterns of the maternal complications in early onset hypertension of pregnancy. BJOG 2007;114(6):741-50.

6. Hwang JL, Hsu MC, Yang YS, et al. Hypertensive disorders of pregnancy: analysis of 110 cases. Taiwan Yi Xue Hui Za Zhi 1989;88(6):572-8.

7. Burrow GN, Duffy TP, Copel JA. Medical complications during pregnancy. $6^{\text {th }}$ edn. Elsevier 2004:43-68. 
8. Hauth JG, Ewell MG, Levine RJ. Pregnancy outcomes in healthy nulliparas who developed hypertension. Calcium for preeclampsia prevention study group. Obstet Gynecol 2000;95(1):24-8.

9. Eskenazi B, Fenster L, Sidney S. A multivariate analysis of risk factors for preeclampsia. JAMA 1991;266(2): 237-41.

10. de Swiet M. Medical disorders in obstetric practice. $4^{\text {th }}$ edn. Blackwell 2002:159-97.

11. Brown MA, Buddle ML. Hypertension in pregnancy: maternal and fetal outcomes according to the laboratory and clinical features. MJA 1996;165(7):360-65.

12. Ros HS, Cnattingius S, Lipworth L. Comparison of risk factors for preeclampsia and gestational hypertension in a population-based cohort study. Am J Epidemol 1998;147(11):1062-70.

13. Sezik M, Ozkaya O, Sezik HT, et al. Expectant management of severe preeclampsia presenting before 25 week of gestation. Med Sci Monit 2007;13(11):CR523-27.

14. Dekker G, Sibai BM. Primary, secondary and tertiary prevention of preeclampsia. Lancet 2001; 357:209-15.
15. Jophy R, Mhasker A, Misquitta D. Maternal and perinatal outcome associated with HELLP syndrome in PIH/eclampsia. J Obstet Gynaecol India 2004; 54(2):147.

16. Cincotta RB, Brennecke SP. Family history of preeclampsia as a predictor of preeclampsia in primigravidas. International Journal of Gynaecology \& Obstetrics 1998;60(1):23-7.

17. Gonzalez AL, Ulloa Galvan G, Alpuche G, et al. Risk factors for preeclampsia. Multivariate analysis. Ginecol Obstet Mex 2000;68:357-62.

18. Ros HS, Lichtenstein P, Lipworth L, et al. Genetic effects on the liability of developing pre-eclampsia and gestational hypertension. Am J Med Genet 2000;91(4):256-60.

19. Sibai BM, Ewell M, Levine RJ, et al. Risk factors associated with preeclampsia in healthy nulliparous women. The Calcium for preeclampsia prevention (CPEP) study group. Am J Obstet Gynecol 1997;177(5):1003-10.

20. Branch DW, Porter TF, Rittenhouse L, et al. Antiphospholipid antibodies in women at risk for preeclampsia. Am J Obstet Gynecol 2001;184(5):825-34.

21. Moore MP, Redman CW. Case control study of severe preeclampsia of early onset. BMJ (Clinical Research Ed) 1983;287(6392):580-3. 